\title{
Adnexal Mass
}

National Cancer Institute

\section{Source}

National Cancer Institute. Adnexal Mass. NCI Thesaurus. Code C35155.

An abnormal growth in the ovary, fallopian tube, or surrounding connective tissue. 